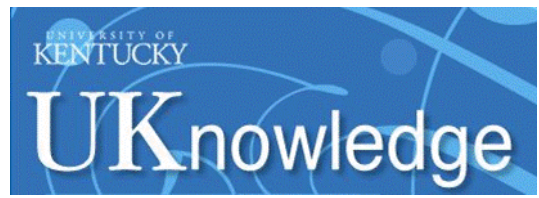

University of Kentucky

UKnowledge

3-19-2021

Correction to Some Statements about Aluminum in Sulaiman et al.

Robert A. Yokel

University of Kentucky, ryokel@email.uky.edu

Right click to open a feedback form in a new tab to let us know how this document benefits you.

Follow this and additional works at: https://uknowledge.uky.edu/ps_facpub

Part of the Pharmacy and Pharmaceutical Sciences Commons 


\section{Correction to Some Statements about Aluminum in Sulaiman et al.}

\section{Digital Object Identifier (DOI)}

https://doi.org/10.1021/acs.chemrestox.1c00098

\section{Notes/Citation Information}

Published in Chemical Research in Toxicology, v. 34, issue 4, 935.

Copyright @ 2021 American Chemical Society

This document is the unedited author's version of a Submitted Work that was subsequently accepted for publication in Chemical Research in Toxicology, copyright (c) American Chemical Society after peer review. To access the final edited and published work, see https://doi.org/10.1021/acs.chemrestox.1c00098.

The copyright holder has granted the permission for posting the article here. 
Correction to some statements about aluminum in Sulaiman et al.

Robert A. Yokel, Ph.D.

Department of Pharmaceutical Sciences

College of Pharmacy

University of Kentucky Academic Medical Center

Lexington, KY, 40536-0596, US

e-mail: ryokel@uky.edu

I am addressing the following statements in Sulaiman R, Wang M, Ren X. 2020. Exposure to aluminum, cadmium, and mercury and autism spectrum disorder in children: A systematic review and meta-analysis. Chem. Res. Toxicol. Published ASAP, September 29, 2020.

- "Environmental levels of Al vary depending on location and weather, with industrial cities recording air concentrations up to $3 \mathrm{mg} / \mathrm{m}^{3}$." The cited reference ${ }^{1}$ states: "In general, background levels of aluminum in the atmosphere are low, typically ranging from about 0.005 to $0.18 \mu \mathrm{g} / \mathrm{m}^{3}$. Much higher levels are routinely observed in urban and industrial locations. A mean aluminum concentration of $474.6 \mathrm{ng} / \mathrm{m}^{3}$ (range $38.4-2,619.6 \mathrm{ng} / \mathrm{m}^{3}$ ) was reported in particulate matter collected in air from downtown Rio de Janeiro, Brazil." 2,619.6 ng $/ \mathrm{m}^{3}$ would round up to $3 \mu \mathrm{g} / \mathrm{m}^{3}$, not $\mathrm{mg} / \mathrm{m}^{3}$.

- "The FDA has no limits on the amount of Al in foods or medicines".

- There is a limit to the amount of aluminum in biologics, such as vaccines. The amount of aluminum in the recommended individual dose of a biological product shall not exceed: (1) 0.85 milligrams if determined by assay; (2) 1.14 milligrams if determined by calculation on the basis of the amount of aluminum compound added; or (3) 1.25 milligrams determined by assay. 21CFR610.15 https://www.accessdata.fda.gov/scripts/cdrh/cfdocs/cfcfr/cfrsearch.cfm?fr=610.15

- There are limits to aluminum in large and small volume parenterals used in total parenteral nutrition. The aluminum content of large volume parenteral (LVP) drug products used in total parenteral nutrition (TPN) therapy must not exceed 25 micrograms per liter. ... the maximum level of aluminum present at expiry must be stated on the immediate container label of all small volume parenteral (SVP) drug products and pharmacy bulk packages (PBPs) used in the preparation of TPN solutions. 21CFR201.323

https://www.accessdata.fda.gov/scripts/cdrh/cfdocs/cfcfr/cfrsearch.cfm?fr=201.323

- "The body burden of $\mathrm{Al}$ is difficult to measure because most of it is stored in bone and the brain". Normal human tissue aluminum levels are 1.0, 1.2, 2.2, 2.6, 3.3, 4.1, and $43 \mathrm{mg} / \mathrm{kg}$ in heart, muscle, brain gray matter, spleen, bone, liver, and lung ${ }^{2}$. Based on organ weights, $\sim 54 \%$ of aluminum is in the skeleton and $1 \%$ in the central nervous system ${ }^{3}$.

- "Al in blood binds to albumin". Approximately $90 \%$ of aluminum in plasma is bound to transferrin. Most of the remainder is bound to citrate ${ }^{4,5}$.

References:

${ }^{1}$ ATSDR (Agency for Toxic Substances and Disease Registry). (2008) Toxicological profile for aluminum. US Department of Health and Human Services, Public Health Service, Agency of Toxic Substances and Disease Registry, 357 pages.

http://www.atsdr.cdc.gov/toxprofiles/tp.asp?id=191\&tid=34

${ }^{2}$ Alfrey AC. 1983. Aluminum. Advances in Clinical Chemistry 23: 69-91. 
${ }^{3}$ Priest ND. 2004. The biological behaviour and bioavailability of aluminium in man, with special reference to studies employing aluminium-26 as a tracer: review and study update. Journal of Environmental Monitoring 6: 375-403.

${ }^{4}$ Martin RB, Savory J, Brown S, Bertholf RL, Wills MR. 1987. Transferrin binding of $\mathrm{Al}^{3+}$ and $\mathrm{Fe}^{3+}$. Clinical Chemistry 33: 405-407.

5 Yokel RA, McNamara PJ. 2001. Aluminum toxicokinetics: An updated mini-review. Pharmacology and Toxicology 88: 159-167. 